\title{
Viability and Biochemical Content Changes in Seed Storage of Jabon Putih (Anthocephalus Cadamba (Roxb) Miq.)
}

\author{
Naning Yuniarti*, Nurhasybi \\ Balai Penelitian Teknologi Perbenihan Tanaman Hutan Jl. Pakuan Ciheuleut PO Box 105 Bogor, Indonesia 16144
}

Received April 16, 2015/Accepted August 15, 2015

\begin{abstract}
Seed deterioration is the process of deteriorated seed in view of viability that changed the physiological and chemical content. The aim of this research is to find out the effect of moisture content and storage on viability and biochemical content of jabon putih seed. Completely Randomized Design was used for decreasing moisture content based on seed drying time for 0, 24, 48, 72, 96, 120 hours, and Completely Randomized Factorial Design was used for the combination of moisture content (drying time for 0, 24, 48, 72, 96, 120 hours) and room storage (ambient room, air-conditioned room, refrigerator). The results of this research are: (1) seed drying time and seed storage affected the change of seed viability and biochemical content, (2) seed drying time and seed storage influence significantly the value of moisture content, germination percentage, and biochemical content (lipid, carbohydrate, protein), (3) The longer time of seed drying and seed storage has decreased the seed moisture content, germination percentage, and the carbohydrate content, but it has increased the content of lipid and protein, and (4) the seeds were stored in refrigerator has better viability compared to dry cold storage and ambient room.
\end{abstract}

Keywords:biochemical, jabon putih, seed drying, seed storage, viability

*Correspondence author,email:naningbtp@yahoo.co.id,Tel.: +62-251-8327768

\section{Introduction}

Jabon putih (Anthocephalus cadamba (Roxb) Miq.) is belong to the family of Rubiaceae. Distribution of the species are in most of West Java and East Java, the whole of Sumatra, Kalimantan and Sulawesi, Nusa Tenggara Barat and Irian Jaya (Martawijaya et al. 1989). Considering its potential, jabon putih as a timber-forest species are very good to be developed. Increasing the number and quality of the seeds need to be considered to ensure the procurement of plant material in the planting program. Such improvements, including through the right time in the seed collection, good seed handling and right and secure storage. If these phases followed the planting program is likely to be more successful.

One of the problems encountered in providing high quality seed is the maintenance of seed viability during storage, which can be done by lowering the rate of respiration. High respiration rate can lead to rapid loss of seed reserves of energy and food supplies, especially in the embryo that can result in not being able to germinate and this is deterioration process of the seed (Widajati et.al. 2012). Naturally, jabon putih seed will decline in viability as increasing time. In general, the seeds will face deteriorated symptoms, or called the setback chronological setback (Yuniarti et al. 2008c). Thus the safe storage of seeds intended to maintain seed viability remained high until the seeds are used for planting.

Seed deterioration is defined as the decline in the quality of the seed, nature or viability that resulted in low vigor, bad crops and declining results. Processes that occur in seed deterioration are as follows (Copeland 1976): (1) reduced respiration, (2) increasing fatty acid, (3) reduced the rate of germination, (4) reduction in the rate of growth and development, (5) loss of energy to grow, (6) increasing abnormal seedling, (7) loss of enzyme activity, (8) decreasing of seed germination, (9) loss of shelf life, (10) decrease in synchrony grow, (11) color changes, and (12) died.

Physiologically, seed decline is indicated by the color change of the seed, delayed germination, and the growth of abnormal seedlings (Sadjad 1999), a decrease in the appearance of seedlings in the field (field emergence), inhibition of plant growth and development, increased sensitivity to extreme environments that ultimately can reduce crop production (Panjaitan 2010). There are two issues related to the process of seed deterioration during storage period is chronological setback related to the elements of time and physiological deterioration caused by various environmental factors. Deterioration of seed quality is deteriorated seed viability that enable to change the seed thoroughly either physically, physiologically or chemically. Some of the factors that affect seed viability during storage, among others, temperature, seed moisture content, relative humidity and oxygen gas (Sudjindro 1994). The changes during storage conditions can cause changes in the rate of respiration. Respiration rate continues to increase when the ambient temperature rises because of the occurrence of such 
inactivation of enzymes, nutrients or oxygen runs out of reserves or as carbon dioxide accumulates. During storage, the seeds that contain a lot of fat more easily damaged than the seed that contains starch or protein (Sudjindro 1994). By knowing the biochemical content, it can be predicted that the potential seed storage technique or proper testing can be specified for the seed. In connection with the above facts, the purpose of this study was to determine the impact of a decrease in moisture content and storage to the changes of seed viability and biochemical content of jabon putih seed.

\section{Methods}

Seed quality testing was carried out in the laboratory and greenhouse of Forest Tree Seed Technology Research Centre in Bogor. Biochemical analysis (carbohydrate, protein, fat) was performed in the Laboratory of SEAMEO-Biotrop in Bogor. The study was conducted over 3 months, starting June-September 2013. Jabon putih seed used in this study was collected from KHDTK (Forest Research Station) Borisallo in South Sulawesi. The materials and tools including sterilized media of mixture of soil and sand, aluminum foil, silica gel, sprayer, distilled water, zambient room, DCS, refrigerator, alcohol, and stationery.

1 Seed moisture content, germination and bichemichal content

a Seed drying time of treatments used in this study were 0 , $24,48,72$ hours using 4 replicates of each tratment.

b The number of seeds in each treatment requires 4 replicates@5 g for determination of moisture content, 4 replicates@100 g for biochemistry analysis (protein, fat, carbohydrates), and 4 replications @ $0.1 \mathrm{~g}$ for germination testing.

c Determination of seed moisture content, seed germination, and the content of biochemist seed (protein, fat, carbohydrate) were conducted at any period of drying. Determination of seed moisture content usesd an oven at a temperature of $103+2{ }^{\circ} \mathrm{C}$ for 18 hours. A mixture of sand and soil $(1: 1 \mathrm{v} / \mathrm{v})$ was used for germination media.

d Responses observed in this study were seed water content, germination, and biochemical contents (carbohydrates, proteins, fats).

2 Seed moisture content reduction and storage

a There were 2 factors used in this study, i.e. the drying time $(0,24,48,72$, hours) and rooms for seed storage (ambient room, refrigerator, and dry cold storage/DCS).

b The number of seeds in each treatment requires 4 replications@5 g seed for testing moisture content, 4 replications@100 g seed for biochemical analysis (carbohydrates, proteins, fats), and 4 replications @ $0.1 \mathrm{~g}$ seed for germination testing. The treated seed were inserted into cloth bags.

c Seeds in the cloth bag were put into the box which contain of silica gel and placed for $0,24,48,72$ hours.

d After drying for 0, 24, 48 and 72 hours, the seeds of each level drying time were stored in a room temperature (28$\left.31{ }^{\circ} \mathrm{C}, 70-80 \% \mathrm{RH}\right), \mathrm{DCS}\left(4-8{ }^{\circ} \mathrm{C}, 40-60 \% \mathrm{RH}\right)$ and refrigerator $\left(0-5{ }^{\circ} \mathrm{C}, 40-50 \% \mathrm{RH}\right)$. Seed container used was aluminum foil that tightly closed. The seeds were stored for 2 weeks.

e Determination of seed moisture content, seed germination, and the content of biochemistry (protein, fat, carbohydrate) were conducted for every level drying time at the end of storage.

Data Analysis A completely randomized design (CRD) was employed with two way factor of drying rates of $0,24,48,72$ hours and rooms for seed storage (ambient room, refrigerator, and dry cold storage). Data were analyzed by using analysis of variance (ANOVA). If there was a significant effect then followed by test Least Significant Difference (LSD) test.

\section{Results and Discussion}

Moisture content decrease by drying time Summary of analysis of variance of drying effect on water content, germination, and biochemistry (fat, carbohydrate, and protein) of jabon putih seed is presented in Table 1.

Based on the results of variance, the drying time significantly affected the value of water content, germination percentage, and the content of fat, carbohydrates, and protein of jabon putih seeds. Treatments of seed drying that made some difference to the moisture content, germination percentage and biochemical content of the seeds can be seen in Figure 1 and Figure 2.

Based on the results indicate that during the drying there was a change in the viability and biochemical content of the seeds of jabon putih. Drying time of $0 \mathrm{~h}$ (control), the value of the initial moisture content of the jabon seed is equal to $9.15 \%$, with germinating seed was 1140 pure seeds $0.1 \mathrm{~g}^{-1}$, protein content of $13.4 \%$, fat of $19.9 \%$, and carbohydrates of $46.7 \%$. Moisture content decreased after drying for 24 hours $(8.59 \%)$ and continued to decline until the drying time of 48 hours $(8.11 \%)$. When drying time from 48 hours to 72 hours (7.94\%), the water content was relatively stable and did not give significantly different. At 72 hours of drying time, germinating seed was 953 pure seeds $0.1 \mathrm{~g}^{-1}$, germinating rate of 42.65 seeds per day, protein content of $14.4 \%$, fat of $21 \%$, and $44.1 \%$ of carbohydrate. According to Rohandi and Widyani (2010), declining process in seed moisture content after facing more than 72 hours drying time can cause significant decrease in seed germination. Seed moisture content is an important factor with respect to their effects on

Table 1 Summary of analysis of variance effect of drying time to moisture content, germination percentage, and biochemist content (fat, carbohydrate, and protein) of jabon putih seed

\begin{tabular}{lcc}
\hline \multicolumn{1}{c}{ Parameter } & F calculation & F table $(5 \%)$ \\
\hline Moisture content & $34,04^{*}$ & 4,066 \\
Germination percentage & $12,57^{*}$ & 3,490 \\
Fat & $38,50^{*}$ & 4,387 \\
Carbohydrate & $12,82^{*}$ & 4,387 \\
Protein & $27,32^{*}$ & 4,387 \\
\hline
\end{tabular}

* = significant at $95 \%$ confidence level 


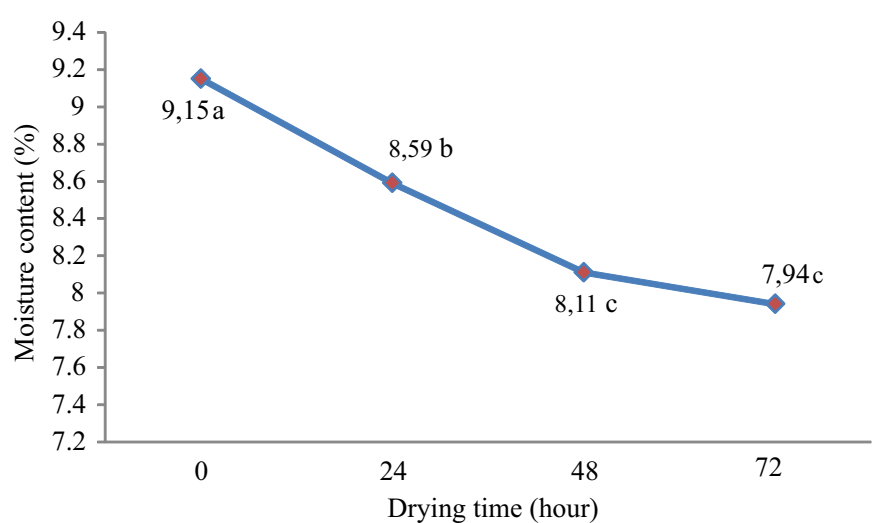

Values followed by the same letter from left to right are not significantly different at $95 \%$ confidence level

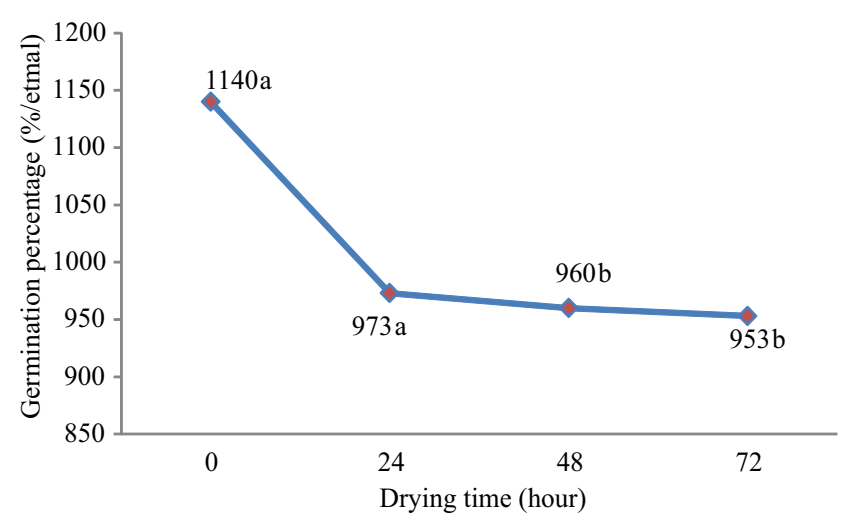

Values followed by the same letter from left to right are not significantly different at $95 \%$ confidence level

Figure 1 Average of moisture content and germination percentage of jabon putih seed based on drying time (Least Significance Different test).

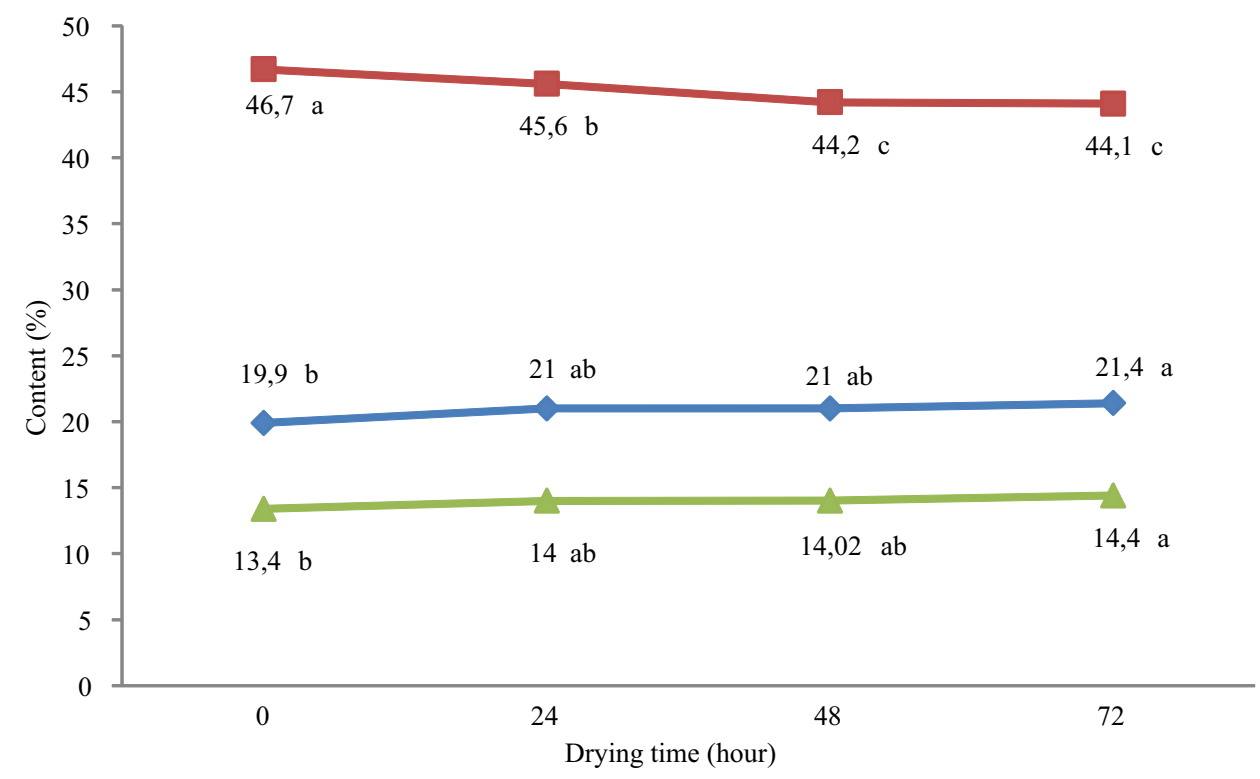

Values followed by the same letter from left to right are not significantly different at $95 \%$ confidence level

Figure 2 Average of fat, carbohydrate, and protein of jabon putih seed based on drying time (Least Significance Different Test). Fat $(\vec{\sim})$, Carbohidrat $(-\vec{r})$, Protein $(\overrightarrow{-})$.

seed viability. This indicates that seed deterioration caused by moisture content reduction (Sadjad 1999) physiologically indicated by delayed germination, germination and growth decline. Judging from the content of biochemistry (protein, fat, carbohydrates), it appears that jabon putih seeds have the highest levels of carbohydrate $(46.7 \%)$ compared to the levels of protein (13.4\%) and fat (19.9\%) in control condition ( 0 hour drying time). The longer the drying time, will lead to a slight increase in the levels of fat and protein, as well as a slight decrease in carbohydrate. In the process of drying (moisture reduction) fat content in the seeds tend to increase in line with decreasing water content and germination. (Yuniarti et al. 2008 a). The lower moisture content will increase the fat content in terms of seed weight, but it will decrease seed germination when the seed need water uptake that identical to oxygen uptake to germinate (Bonner et al. 2008).

Jabon putih seed had the highest carbohydrate content compared to protein and the seed can be cathegorized as orthodox. One characteristic of orthodox seeds is to have a high carbohydrate content. Seed which has a relatively high carbohydrate content has a high shelf to protect because carbohydrates are food for reserves to survive so that the seeds can survive during storage and grow into seeedlings (Justice \& Bass 2002).

Moisture content decrease and storage Summary of analysis of variance of drying time and room storage effect on moisture content, germination, and biochemistry (fat, carbohydrate, and protein) of jabon putih seed presented in 
Table 2 Summary of analysis of variance effect of drying time and room storage to moisture content, germination percentage, and biochemical content (fat, carbohydrate and protein) of jabon putih seed

\begin{tabular}{llcc}
\hline Parameter & \multicolumn{1}{c}{$\begin{array}{c}\text { Source of } \\
\text { variation }\end{array}$} & $\begin{array}{c}\mathrm{F} \\
\text { calculation }\end{array}$ & $\begin{array}{c}\text { F Table } \\
(5 \%)\end{array}$ \\
\hline Moisture content & Drying time & $12,93 *$ & 3,009 \\
& Store room & $47,95 *$ & 3,403 \\
& Interaction & $23,62 *$ & 2,508 \\
\hline Germination percentage & Drying time & $11,98 *$ & 2,866 \\
& Store room & $7,43 *$ & 3,259 \\
& Interaction & $3,06 *$ & 2,364 \\
\hline Fat & Drying time & $136,64 *$ & 2,773 \\
& Store room & $697,39^{*}$ & 3,555 \\
& Interaction & $122,41^{*}$ & 2,412 \\
\hline Carbohydrate & Drying time & $10,99 *$ & 2,773 \\
& Store room & $251,89 *$ & 3,555 \\
& Interaction & $28,52^{*}$ & 2,412 \\
\hline Protein & Drying time & $3,71 *$ & 2,773 \\
& Store room & $4,44 *$ & 3,555 \\
& Interaction & $3,82 *$ & 2,412 \\
\hline
\end{tabular}

$*$ = significant at $95 \%$ confidence level

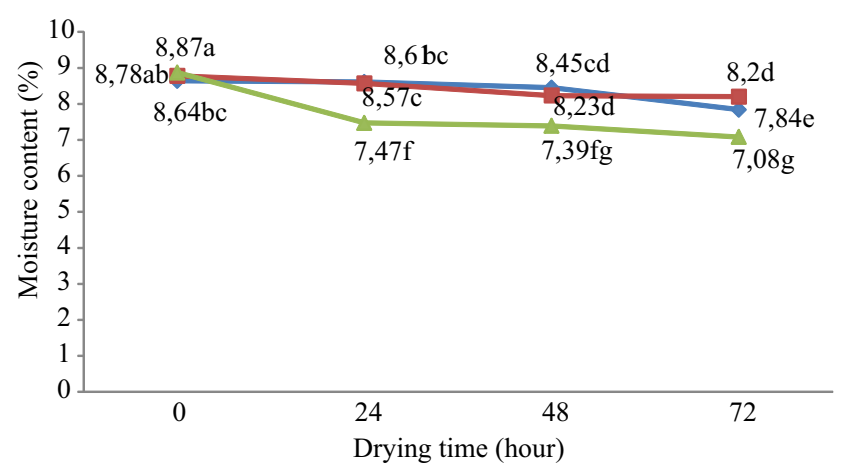

Values followed by the same letter from left to right are not significantly different at $95 \%$ confidence level

Figure 3 Average moisture content of jabon putih seed based on interaction of drying time and room storage (Least Significance Different test). Ambient room $(\smile)$, Dry Cold Storage ( $\bullet)$, Refrigerator $\left(-{ }^{-}\right)$.

Table 2. Based on the analysis of variance, drying time and room storage significantly affected on the value of water content, germination, and biochemical content of jabon putih seed. To find out the treatment that made significantly difference, it was tested by LSD (Figure 3, Figure 4, Figure 5, Figure 6, and Figure 7).

Based on the results, it was indicated that during drying and storage occur changes in the viability and biochemical content of the seeds of jabon putih. Moisture content and seed germination of jabon putih tended slightly decreases after

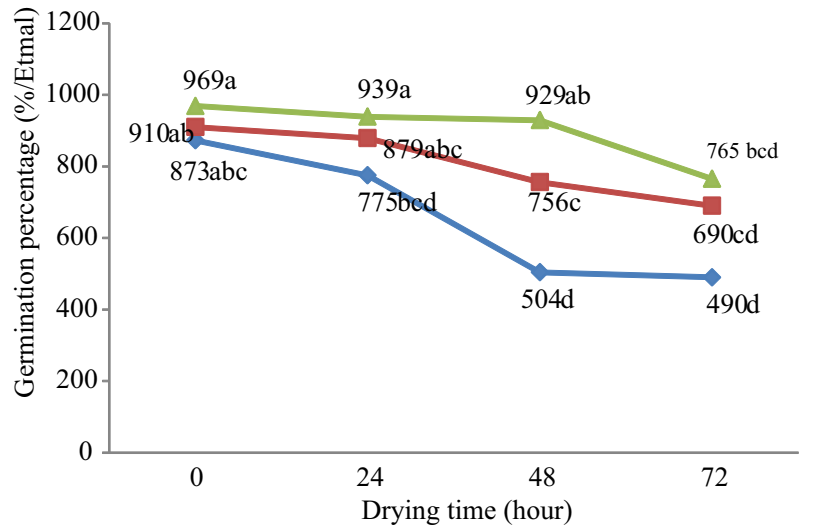

Values followed by the same letter from left to right are not significantly different at $95 \%$ confidence level

Figure 4 Average of germination percentage of jabon putih seed based on interaction of drying time and room storage (Least Significance Different test). Ambient room $(\neg)$, Dry Cold Storage $(-b)$, Refrigerator $\left(-{ }^{-}\right)$.

seed drying and storage. Naturally jabon putih seed had a little deteriorated with increasing time in storage. According to Sadjad (1999), the process of seed deterioration during storage is related to time and environmental factors.

The seed in decreasing process will decline in energy of germination and also to the ability to grow on suboptimum conditions. Deteriorating seed symptoms can be observed in terms of biochemistry, eg enzyme activity, respiration rate, and leakage metabolites (Widajati et. al 2012). Recalcitrant seeds deterioration due to internal and external factors 


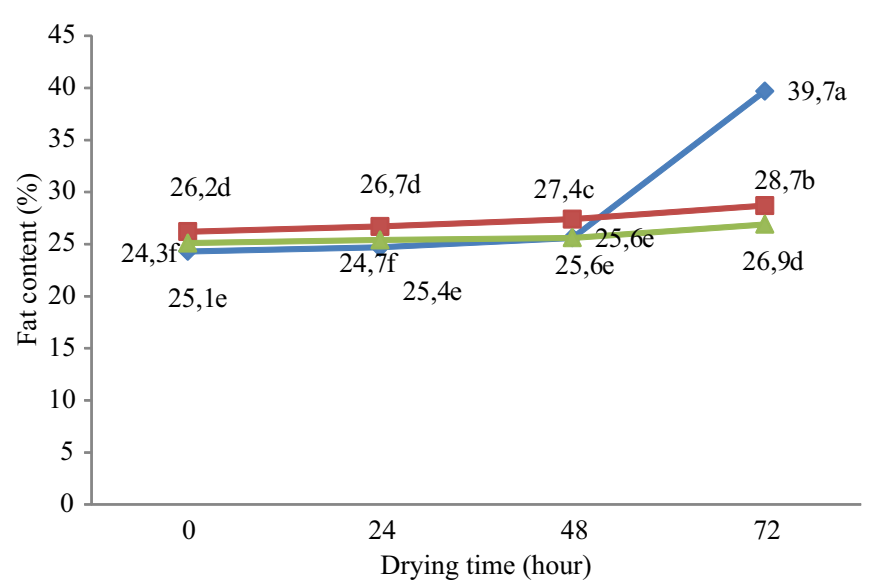

Values followed by the same letter from left to right are not significantly different at $95 \%$ confidence level

Figure 5 Average of fat content of jabon putih seed based on interaction of drying time and room storage (Least Significance Different Test). Ambient room ( - ), Dry Cold Storage $(-<)$, Refrigerator $(-)$.

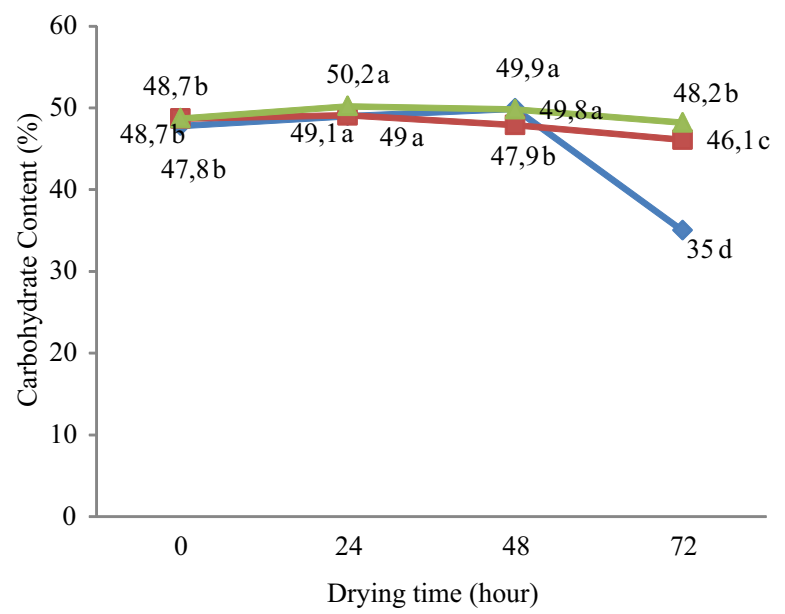

Values followed by the same letter from left to right are not significantly different at $95 \%$ confidence level

Figure 6 Average of carbohydrate content of jabon putih seed based on interaction of drying time and room storage (Least Significance Different Test). Ambient room $(\sim)$, Dry Cold Storage ( $-\boldsymbol{-})$, Refrigerator $(-1-)$.

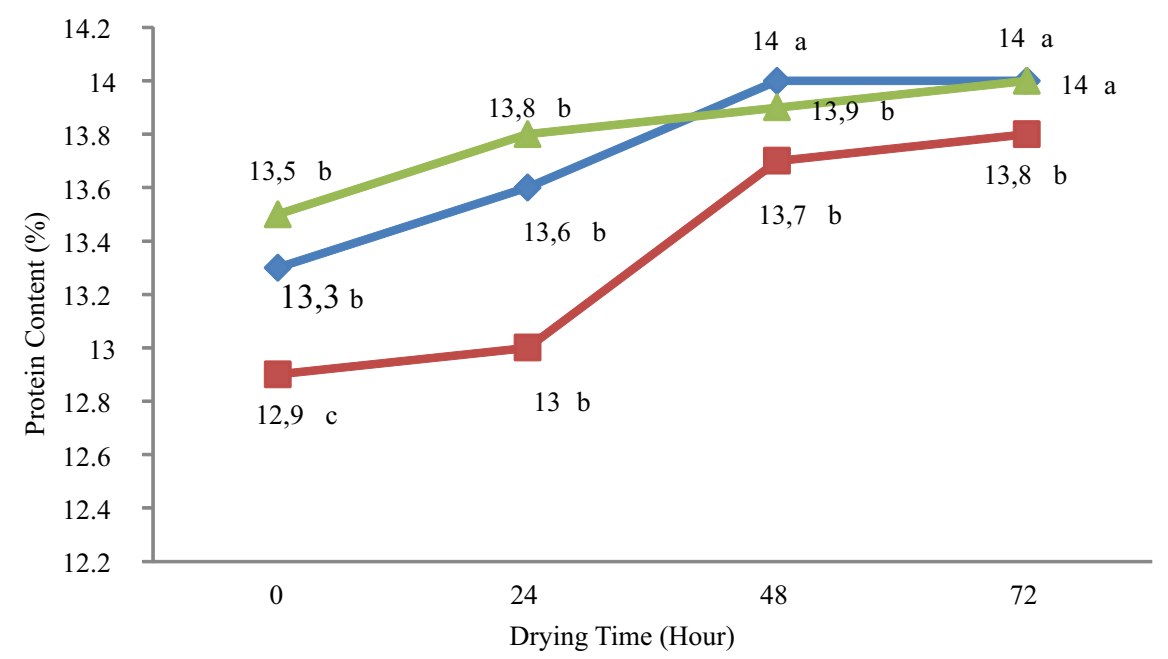

Values followed by the same letter from left to right are not significantly different at $95 \%$ confidence level

Figure 7 Average of protein contain of jabon putih seed based on interaction of drying time and room storage (Least Significance Different Test). Ambient room $(\neg)$, Dry Cold Storage $(-\rightarrow)$, Refrigerator $(-)$.

characterized by a decrease in germination, an abnormal increase in the number of sedlings, decrease the appearance of seedlings in the field (field emergence), inhibition of plant growth and development, increased sensitivity to extreme environments that ultimately can reduce crop production.

Jabon putih seed stored in the refrigerator $\left(0-5^{\circ} \mathrm{C}, 40-\right.$ $50 \% \mathrm{RH})$ was enable to produce better seed viability than those seeds stored in the DCS $\left(4-80^{\circ} \mathrm{C}, 40-60 \% \mathrm{RH}\right)$ and the ambient room (temperature $28-31{ }^{\circ} \mathrm{C}, 70-80 \% \mathrm{RH}$ ). This is consistent with the nature of the jabon putih seed belonging. Orthodox seed is a seed that can be dried to a low moisture content, and stored for long time at high temperature and low humidity without causing a significant decrease in seed viability. Orthodox seed has a tolerant properties at moisture content of $5-7 \%$, with a temperature of $0-20{ }^{\circ} \mathrm{C}$ (Schmidt
(2000).

According to Berjak and Pammenter (2008), the best way to maintain the viability of the seed is to keep it at a low temperature and reducing contamination with fungi. As the seeds of Trichilia dregeana that can be stored several months at a temperature of $16^{\circ} \mathrm{C}$ (Goveia et al. 2004), seed T. emetica (Kioko et al. 2006) and T. occidentalis (Ajayi et al. 2006) kept at a temperature of $6{ }^{\circ} \mathrm{C}$.

Judging from the content of biochemical (fats, carbohydrates, proteins), after storage, jabon putih seed slightly increased levels of fat and protein, as well as a slight decrease in carbohydrate content. This is indicated that the seeds of jabon putih in this study showed symptoms of seed deterioration as over time (chronological setback).

Biochemical indications in seed decline is the change of 
enzyme activity, respiration rate, food reserves, changes in the membrane, chromosome damage and accumulation of toxins. Fatty acids can result in damage to the cell membrane (Tatipata 2008). Increasing lipid and protein content in the seed were possibly due to seed defense mechanism against moisture content reduction. Increasing lipid can lead to delay seed metabolism. Disturbed seed metabolism resulting in a decrease of seed viability of Diospyros celebica (Yuniarti et al. 2008b).

The decline in water levels and an increase in free fatty acids cause a decrease in viability and vigor. High accumulation of fatty acids in the seed will make the seed have no energy to germinate, since no further processed into energy (Tresniawati et. al. 2014).

High fatty acid content in the seed is also an indication of a high respiration process which causes energy loss for seed germination. Increased fat and protein content in the seed thought to be the defense mechanism of the seed during storage. While the decrease in carbohydrate content indicates a decrease in seed defense which resulted in a decrease in seed viability (Yuniarti et al. 2013).

According to Syamsuwida and Aminah (2007), and Syamsuwida \& Aminah (2005), the biochemical changes in the seed during storage showed an increase in carbohydrate, protein and electrical conductivity (EC) and a decrease in fat content. The change of biochemical content of proteins, fats and carbohydrates in storage indicated seed deterioration.

The seeds with a high fat content requires special treatments in handling, otherwise will end up with a loss of viability and ability to germinate (Balesevic-Tubic et al. 2007). Liu et al. (2006) showed that the proportion of fatty acids in membrane phospholipids in recalcitrant seeds is higher than orthodox seeds. In some cases it was found that increasing the fat content due to the presence of fungi during storage in humid conditions, e.g Jatropha curcas (Worang et al.2008).

Justice and Bass (2002) states that the seed which has a relatively high carbohydrate content has a high shelf. Carbohydrates are food for seed reserves to survive so that the seeds can survive during storage and grow into seedlings. Carbohydrate content in the seeds of jabon putih slightly decreased during storage. The presence of carbohydrates in seeds consisting of component sugars (sucrose) as a substrate forming carbohydrate, showed a defense against drying as well as protein. The decrease in carbohydrate content indicates a decrease in seed defense means a decline in seed viability. This is shown by the decrease in seed germination jabon putih during storage.

After storage, the fat content of jabon putih seed only slightly increased. High fatty acid content in the seed is also an indication of a high respiration process which causes loss energy for seed germination (Yuniarti et. al 2008c). According to Sudjindro (1994), the seeds that have a high fat content, can be easily damaged during storage. High fatty acid content in the seed is also an indication of a high respiration process which causes energy loss for seed germination. During storage, the seeds that contain a lot of fat more easily damaged than the seed that contains starch or protein. After the seed storage, protein levels in jabon putih seed slightly increase with decreasing water content and germination. Changes in the intensity and type of protein is controlled by adjusting the activity of DNA in the seed itself. Increased levels of this protein is thought to be a defense mechanism against the decrease in seed moisture content during storage. It also indicates the defense of seeds in optimal conditions. In addition, the synthesis of specific proteins is needed to sustain embryo dormancy (Gifford 1993).

\section{Conclusion}

Decrease in seed moisture content in storage leads to the changes in the viability and biochemical content of jabon putih seed. Treatments in decreasing of moisture content based on drying time and storage significantly affect the value of water content, germination, and biochemical content (fat, carbohydrate, protein) of jabon putih seed. The longer time for seed drying and storage will cause a slight decrease in water content and germination, slightly increased of fat and protein content, as well as slight decrease of carbohydrates on jabon putih seed. Jabon putih seed stored in the refrigerator can maintain seed viability better than in the dry cold storage and ambient room.

\section{Acknowledgment}

The authors would like to thank the Forestry Research Institute of Makassar for providing the seed material for this research. Thanks also addressed to the technicians for helping in seed testing in the laboratory.

\section{References}

Ajayi SA, Patricia B, Kioko J, Dulloo ME, Vodouhe RS. 2006. Responses of fluted pumpkin (Telfairia occidentalis Hook.f.) seeds to desiccation, chilling and hydrated storage. South African Journal of Botany 72:544-550. http://dx.doi.org/10.1016/j.sajb.2006. 02.001

Balešević-Tubić S, Tatić M, Miladinović J, Pucarević M .2007. Changes of faty acidscontent and vigour of sunflower seed during natural aging. Helia 30(47):61-67. http://dx.doi.org/10.2298/HEL0747 061B

Berjak P, Pammenter NW. 2008. From Avicennia to zizania: seed recalcitrance in perspective. Annals of Botany (ANN BOT-LONDON) 101(2):213-228.

Bonner FT, Karrfalt RP and Nisley RG. 2008. The woody plant seed manual. USDA Forest Service. Washington DC. 1224 p.

Copeland LO. 1976. Principles of Seed Science and Technology. Minnesota: Burgess Publishing Company.

Gifford, DJ. 1993. Loblolly Pine Seed Dormancy; The Relationship Between Protein, Synthesis in The Embryo and Mega Gametophyte and The Loss of Seed Dormancy, In Edward DGW, editor. Dormancy and Barriers to Germination. Proceeding. International Symposium of IUFRO Project Group P2.04.00 (Seed 
Problems).

Goveia M, Kioko JI, Patricia B. 2004. Developmental status is a critical factor in the selection of excised recalcitrant axes as explants for cryopreservation. Seed Science Research 14:241-248. http://dx.doi.org/10.1079/SSR 2004173.

Justice OL, Bass LN. 2002. Prinsip dan Praktek Penyimpanan Benih. Translated from: The Principles and Practises of Seed Storage. Roesli R, translator. Jakarta: PT. Raja Grafindo Persada.

Kioko JI, Berjak P, Pammenter NW. 2006. Viability and ultrastructural responses of seeds and embryonic axes of Trichilia emetica to different dehydration and storage conditions. South African Journal of Botany 71:167-176. http://dx.doi.org/10.1016/j.sajb.2005.07.001.

Liu M-S, Chang C-Y, Lin T-P. 2006. Comparison of phospholipids and their fatty acids in recalcitrant and orthodox seeds. Seed Science and Technology 34:443-452. http://dx.doi.org/10.15258/sst.2006.34. 2.19 .

Martawijaya AI, Kartasujana K, Kadir SA, Prawira. 1989. Atlas Kayu Indonesia Jilid II. Bogor: Pusat Penelitian dan Pengembangan Kehutanan.

Rohandi A, Widyani N. 2010. Dampak penurunan kadar air terhadap respon fisiologis dan biokimia propagul Rhizophora apiculata Bl. Jurnal Penelitian Hutan Tanaman 7(4):167-179.

Sadjad S. 1999. Parameter Pengujian Vigor Benih dari Komparatif Ke Simulatif. Jakarta: Grasindo.

Schmidt L. 2000. Pedoman Penanganan Benih Tanaman Hutan Tropis dan Sub Tropis. Jakarta: PT Gramedia.

Syamsuwida D, Aminah A. 2005. Dampak pengeringan dan penyimpanan terhadap perubahan fisiologi dan biokimia benih antok. Jurnal Penelitian Hutan Tanaman 2(2):267-277.

Syamsuwida D, Aminah A. 2007. The change of fat, protein, starch contens and electric conductivity within gaharu (Aquillaria malaccensis) seeds. Jurnal Manajemen Hutan Tropika 13(2):125-130.

Sudjindro. 1994. Indikasi kemunduran viabilitas oleh dampak guncangan pada benih kenaf (Hibiscus cannabinus L.). [disertatation]. Bogor: Program Pasca Sarjana. IPB.

Tatipata A. 2008. Pengaruh kadar air awal, kemasan dan lama simpan terhadap protein membran dalam mitokondria benih kedelai. Buletin Agronomi 36(1):8-16.

Tresniawati C, Murniati E, Widayati E. 2014. Perubahan fisik, fisiologi dan biokimia selama pemasakan benih dan studi rekalsitransi benih kemiri sunan. Jurnal Agronomi Indonesia 42(1):74-79.

Worang RL, Dharmaputra OS, Syarief R, Miftahudin. 2008. The quality of physic nut (Jatropha curcas L.) seeds packed in plastic material during storage. Biotropia 15(1):25-36.

Widajati E, Murniati E. Murniati, Palupi ER, Kartika T, Suhartanto MR, Qadir A. 2012. Dasar Ilmu dan Teknologi Benih. Bogor: IPB Press.

Yuniarti N, Syamsuwida D, Aminah A. 2013. Dampak perubahan fisiologi dan biokimia benih eboni (Diospyros celebica Bakh.) selama penyimpanan. Jurnal Penelitian Hutan Tanaman 10 (2):65-71.

Yuniarti N, Syamsuwida D, Aminah A. 2008a. Dampak pengeringan terhadap perubahan fisiologi dan biokimia benih mimba (Azadirachta indica A. Jusss). Buletin Puslitbang Perhutani 11(1): 728-735.

Yuniarti N, Syamsuwida D, Aminah A. 2008b. Pengaruh penurunan kadar air terhadap perubahan fisiologi dan kandungan biokimia benih eboni (Diospyros celebica Bakh.). Jurnal Penelitian Hutan Tanaman 5(3):191-198.

Yuniarti N, Syamsuwida D, Aminah A. 2008c. perubahan kandungan biokimia dan fisiologi benih mimba (Azadirachta indica A.Jusss) selama penyimpanan. Jurnal Penelitian Hutan Tanaman 5(2):259-267 